\title{
Products and Mechanism of the Reactions of $\mathrm{OH}$ Radicals and $\mathrm{Cl}$ Atoms with Methyl Methacrylate $\left(\mathrm{CH}_{2}=\mathrm{C}\left(\mathrm{CH}_{3}\right) \mathrm{C}(\mathrm{O}) \mathrm{OCH}_{3}\right)$ in the Presence of NOx
}

\author{
María B. Blanco, ${ }^{\dagger}$ Iustinian Bejan, ${ }^{\ddagger}, \S$ Ian Barnes, ${ }^{\ddagger}$ Peter Wiesen, ${ }^{\ddagger}$ and Mariano A. Terue ${ }^{* \dagger} \dagger$ \\ ${ }^{\dagger}$ INFIQC (CONICET- Facultad de Ciencias Químicas, Universidad Nacional de Córdoba), Dpto. de Fisicoquímica, Ciudad \\ Universitaria, 5000 Córdoba, Argentina \\ ${ }^{\ddagger}$ Physikalische Chemie/FBC, Bergische Universitaet Wuppertal, Wuppertal, Germany \\ «Al. I. Cuza” University of Iasi, Faculty of Inorganic and Analytical Chemistry, Iasi, Romania
}

\begin{abstract}
The $\mathrm{OH}$ radical and $\mathrm{Cl}$ atom initiated photodegradation of methyl methacrylate has been investigated in a $1080 \mathrm{~L}$ quartz-glass environmental chamber at 298 $\pm 2 \mathrm{~K}$ and atmospheric pressure of synthetic air using in situ FTIR spectroscopy to monitor the reactants and products. The major products observed in the $\mathrm{OH}$ reaction were methyl pyruvate $(92 \pm 16 \%)$ together with formaldehyde $(87 \pm 12 \%)$ as a coproduct from the $\mathrm{C}_{1}-\mathrm{C}_{2}$ bond cleavage channel of the intermediate 1,2-hydroxyalkoxy radical, formed by the addition of $\mathrm{OH}$ to the terminal carbon of the double bond which is designated $\mathrm{C}_{1}$. For the $\mathrm{Cl}$ atom reaction, the products identified were chloroacetone $(41 \pm 6 \%)$ together with its coproduct formaldehyde $(35 \pm 5 \%)$ and methyl pyruvate $(24 \pm 4 \%)$ together with its coproduct formylchloride $(25 \pm 4 \%)$. The results show that the fate of the intermediate 1,2-chloroalkoxy radical involves not only cleavage of the $\mathrm{C}_{1}-\mathrm{C}_{2}$ bond but also quite substantial cleavage of the $\mathrm{C}_{2}-\mathrm{C}_{3}$ bond. The present results are compared with previous studies of acrylates, showing different branching ratios for the $\mathrm{OH}$ and $\mathrm{Cl}$ addition reactions in the presence of NOx. Atmospheric implications are discussed.
\end{abstract}

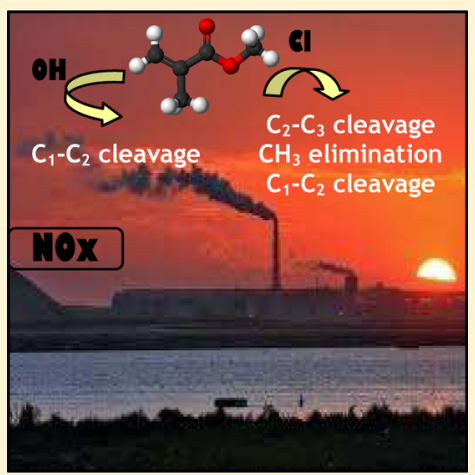

\section{INTRODUCTION}

Esters are oxygenated volatile organic compounds (OVOC) with a large number of commercial uses. They are potential replacements for traditional solvents and are used as diesel fuels or fuel components since they combine acceptable properties with low exhaust emissions and reduced combustion noise. ${ }^{1}$

Methacrylate esters have the structure $\mathrm{CH}_{2}=\mathrm{C}\left(\mathrm{CH}_{3}\right) \mathrm{C}(\mathrm{O})$ $\mathrm{OCH}_{2} \mathrm{R}$ and are widely used in the production of polymers and resins, and as for other acrylic compounds the sources of their emissions are numerous and include the manufacturer of plastics, aircraft, and electronic components. ${ }^{2}$ Methyl methacrylate (MMA) is listed as a high $(\mathrm{H})$ production $(\mathrm{P})$ volume $(\mathrm{V})$ chemical in the OECD (Organisation for Economic Cooperation and Development) integrated HPV database. ${ }^{3}$ Many different kinds of esters including methyl methacrylate have been measured in ambient air. ${ }^{4}$

Emissions of the unsaturated esters to the atmosphere can occur during their production, processing, storage, and disposal, and once in the atmosphere they will be subject to photodegradation mainly by $\mathrm{OH}$ radicals and to a lesser extent $\mathrm{NO}_{3}$ radicals and ozone and, in certain environments, also $\mathrm{Cl}$ atoms. ${ }^{5}$ Oxidation by $\mathrm{Cl}$ atoms has been conventionally thought to have been confined largely to coastal areas and possibly some polluted industrial regions; ${ }^{6-8}$ however, recent field work has presented evidence for $\mathrm{Cl}$ chemistry in continental regions remote from coastal regions, ${ }^{9}$ suggesting that $\mathrm{Cl}$-initiated photooxidation chemistry may play a more important role than previously thought in polluted continental regions.

In order to assess the contribution of the atmospheric photooxidation of methacrylate esters to the formation of photochemical oxidants and secondary organic aerosol (SOA) in urban environments, detailed kinetic and mechanistic information on their tropospheric gas-phase degradation pathways are required. There have been several kinetic studies of the $\mathrm{OH}$ radical, ${ }^{10-14} \mathrm{O}_{3}$-molecule, ${ }^{15-20}$ and the Cl-atom ${ }^{21-23}$ initiated oxidation of unsaturated esters. To date, there have only been three studies on the reactions of acrylates with $\mathrm{NO}_{3}$ radicals. ${ }^{24-27}$

In contrast to the kinetic studies, only a few product studies on the $\mathrm{OH}^{12,13}$ and $\mathrm{NO}_{3}{ }^{26}$ radicals and $\mathrm{Cl}$ atom ${ }^{28}$ initiated oxidation of unsaturated esters have been reported. Blanco et al., ${ }^{12,13}$ reported a qualitative GC-MS product study of the reactions of $\mathrm{OH}$ radicals with methyl methacrylate, ethyl methacrylate, $n$ butyl methacrylate, and $n$-butyl acrylate performed in a collapsible Teflon chamber in which methyl pyruvate, ethyl pyruvate, $n$-butyl pyruvate, and $n$-butyl glyoxylate were identified as unique reaction products, respectively. In a recent study from this laboratory, ${ }^{28}$ performed in a large photoreactor using in situ FTIR analysis, we reported a product study of the $\mathrm{OH}$ and $\mathrm{Cl}$

Received: October 28, 2013

Revised: December 20, 2013

Accepted: January 8, 2014

Published: January 8, 2014 
initiated oxidation of methyl acrylate $\left(\mathrm{CH}_{2}=\mathrm{CHC}(\mathrm{O}) \mathrm{OCH}_{3}\right)$ in which the main product from the $\mathrm{OH}$ reaction was observed to be methyl glyoxylate $\left(\mathrm{HC}(\mathrm{O}) \mathrm{C}(\mathrm{O}) \mathrm{OCH}_{3}\right)$, and methyl 3chloro-2-oxopropanoate $\left(\mathrm{CH}_{2} \mathrm{ClC}(\mathrm{O}) \mathrm{C}(\mathrm{O}) \mathrm{OCH}_{3}\right)$ was tentatively assigned as a major product for the $\mathrm{Cl}$ reaction.

This significant difference in the major products between the reaction of $\mathrm{OH}$ and $\mathrm{Cl}$ with methyl acrylate was similar to what had been observed in a kinetic and product study of the reactions of $\mathrm{OH}$ radicals and $\mathrm{Cl}$ atoms with a fluorotelomer acrylate $\left(\mathrm{CH}_{2}=\mathrm{CHC}(\mathrm{O}) \mathrm{OCH}_{2} \mathrm{CH}_{2} \mathrm{C}_{4} \mathrm{~F}_{9}\right)$ in the air using FTIR to monitor reactants and products. ${ }^{29}$ In this study for the $\mathrm{OH}$ reaction, the evidence supported formation of the a fluorotelomer glyoxylate as the major product, while in the $\mathrm{Cl}$ reaction the experimental observations supported the addition of $\mathrm{Cl}$ and formation of a chain-retaining compound $\mathrm{CHCl}-\mathrm{C}(\mathrm{O}) \mathrm{C}(\mathrm{O})$ $\mathrm{OCH}_{2} \mathrm{CH}_{2} \mathrm{C}_{4} \mathrm{~F}_{9}$.

No quantitative product studies are currently available for $\mathrm{OH}$ radical- and Cl-atom-initiated degradation of methacrylate esters. Since, as stated above, methacrylate esters are widely used in the production of polymers and are released to the atmosphere in substantial amounts, ${ }^{3,4}$ this motivated us to investigate qualitatively and quantitatively the products formed in the $\mathrm{OH}$-radical and Cl-atom degradation of methyl methacrylate (MMA).

$$
\begin{aligned}
& \mathrm{OH}+\mathrm{CH}_{2}=\mathrm{C}\left(\mathrm{CH}_{3}\right) \mathrm{C}(\mathrm{O}) \mathrm{OCH}_{3} \rightarrow \text { products } \\
& \mathrm{Cl}+\mathrm{CH}_{2}=\mathrm{C}\left(\mathrm{CH}_{3}\right) \mathrm{C}(\mathrm{O}) \mathrm{OCH}_{3} \rightarrow \text { products }
\end{aligned}
$$

It is known that the main reaction pathway for both $\mathrm{OH}$ and $\mathrm{Cl}$ with methyl methacrylate is addition to the double bond of the alkene unit in the ester. The reactions have been investigated in the presence of NOx, thus after addition of the oxidant it is wellestablished that the subsequent chemistry will result in the formation of hydroxyalkoxy and chloroalkoxy radicals. The major aim of the work was to assess the relative importance of the different subsequent reaction pathways that are available to the hydroxy- and chloro-alkoxy radicals. The results will contribute to an improved representation of the degradation of methacrylate esters in the atmospheric chemical models used to assess the environmental impact of chemicals and their contribution to photooxidant and SOA formation in the atmosphere.

\section{EXPERIMENTAL SECTION}

All the experiments were performed in a $1080 \mathrm{~L}$ quartz-glass reaction chamber at $298 \pm 2 \mathrm{~K}$ and a total pressure of $760 \pm 10$ Torr of synthetic air $(760$ Torr $=101.325 \mathrm{kPa})$. A detailed description of the reactor can be found elsewhere, ${ }^{30}$ and only a brief description is given here. A pumping system consisting of a turbo-molecular pump backed by a double stage rotary fore pump was used to evacuate the reactor to $10^{-3}$ Torr. Three magnetically coupled Teflon mixing fans are mounted inside the chamber to ensure homogeneous mixing of the reactants. The photolysis system consists of 32 superactinic fluorescent lamps (Philips TL05 40W: $320-480 \mathrm{~nm}, \lambda_{\max }=360 \mathrm{~nm}$ ) and 32 lowpressure mercury vapor lamps (Philips TUV 40W; $\lambda_{\max }=254$ $\mathrm{nm}$ ), which are spaced evenly around the reaction vessel. The lamps are wired in parallel and can be switched individually, which allows a variation of the light intensity, and thus also the photolysis frequency/radical production rate, within the chamber. The chamber is equipped with a White type multiple-reflection mirror system with a base length of $5.91 \pm$ $0.01 \mathrm{~m}$ for sensitive in situ long path infrared absorption monitoring of reactants and products in the spectral range 4000$700 \mathrm{~cm}^{-1}$. The White system was operated at 82 traverses, giving a total optical path length of $484.7 \pm 0.8 \mathrm{~m}$. The IR spectra were recorded with a spectral resolution of $1 \mathrm{~cm}^{-1}$ using a Nicolet Nexus FT-IR spectrometer, equipped with a liquid nitrogen cooled mercury-cadmium-telluride (MCT) detector.

Chlorine atoms were generated by the photolysis of $\mathrm{Cl}_{2}$ with the fluorescent lamps:

$$
\mathrm{Cl}_{2}+h v \rightarrow 2 \mathrm{Cl}
$$

Hydroxyl radicals were generated by the photolysis of $\mathrm{H}_{2} \mathrm{O}_{2}$ with the mercury lamps:

$$
\mathrm{H}_{2} \mathrm{O}_{2}+h v \rightarrow 2 \mathrm{OH}
$$

or by the photolysis of the mixture $\mathrm{CH}_{3} \mathrm{ONO} / \mathrm{NO} /$ air at $360 \mathrm{~nm}$ as follows:

$$
\begin{aligned}
& \mathrm{CH}_{3} \mathrm{ONO}+h v \rightarrow \mathrm{CH}_{3} \mathrm{O}+\mathrm{NO} \\
& \mathrm{CH}_{3} \mathrm{O}+\mathrm{O}_{2} \rightarrow \mathrm{CH}_{2} \mathrm{O}+\mathrm{HO}_{2} \\
& \mathrm{HO}_{2}+\mathrm{NO} \rightarrow \mathrm{OH}+\mathrm{NO}_{2}
\end{aligned}
$$

Where possible, quantification of reactants and products was performed by comparison with calibrated reference spectra contained in the IR spectral databases of the laboratories in Wuppertal and Córdoba.

The initial concentration of methyl methacrylate used in the experiments was $0.5-1.0 \mathrm{ppm}\left(1 \mathrm{ppm}=2.46 \times 10^{13}\right.$ molecules $\mathrm{cm}^{-3}$ at $298 \mathrm{~K}$ and 760 Torr of total pressure). The concentrations of $\mathrm{Cl}_{2}, \mathrm{H}_{2} \mathrm{O}_{2}$, and $\mathrm{CH}_{3} \mathrm{ONO}$ were typically around 5, 7, and $6 \mathrm{ppm}$, respectively. The concentration of added $\mathrm{NO}$ was typically around $4 \mathrm{ppm}$.

The infrared absorption frequency at $1169 \mathrm{~cm}^{-1}$ was used to monitor the concentration-time behavior of methyl methacrylate. Readily identifiable products were monitored at the following absorption frequencies (in $\mathrm{cm}^{-1}$ ): formaldehyde at 2766 , carbon monoxide at 2169 , formyl chloride at 738.6 , methyl pyruvate at 1040, chloroacetone at 1371, and formic acid at 1105 .

The chemicals used in the experiments had the following purities as given by the manufacturer and were used as supplied: synthetic air (Air Liquide, 99.999\%), methyl methacrylate (Aldrich, 99\%), $\mathrm{H}_{2} \mathrm{O}_{2}$ (Interox, 85\%), and $\mathrm{Cl}_{2}$ (Messer Griesheim, >99.8\%). Methyl nitrite was synthesized by the dropwise addition of $50 \% \mathrm{H}_{2} \mathrm{SO}_{4}$ to a saturated solution of sodium nitrite in methanol and was purified by vacuum distillation until a sample of $99 \%$ purity was obtained confirmed by IR spectroscopy.

\section{RESULTS, DISCUSSION, AND CONCLUSIONS}

To investigate the mechanisms of the $\mathrm{OH}$-radical and $\mathrm{Cl}$-atom initiated oxidation of methyl methacrylate, mixtures of $\mathrm{H}_{2} \mathrm{O}_{2}$ / $\mathrm{NO} /$ ester/air or $\mathrm{CH}_{3} \mathrm{ONO} / \mathrm{NO} /$ ester/air and $\mathrm{Cl}_{2} / \mathrm{NO} /$ ester/ air were irradiated for periods of around $20 \mathrm{~min}$ during the course of which infrared spectra were recorded with the FTIR spectrometer. Typically, 64 interferograms were coadded per spectrum over a period of approximately $1 \mathrm{~min}$, and 15-20 such spectra were collected during the course of the experiment.

Dark reactions, photolysis of the methyl methacrylate in the absence of radical precursor reactions, and wall losses were negligible compared to the loss that occurred on $\mathrm{OH}$ radical or $\mathrm{Cl}$ atom photoinduced degradation. ${ }^{14}$

To facilitate the discussion of the results, exemplary reaction schemes are shown for the reactions of $\mathrm{OH}$ and $\mathrm{Cl}$ with methyl 


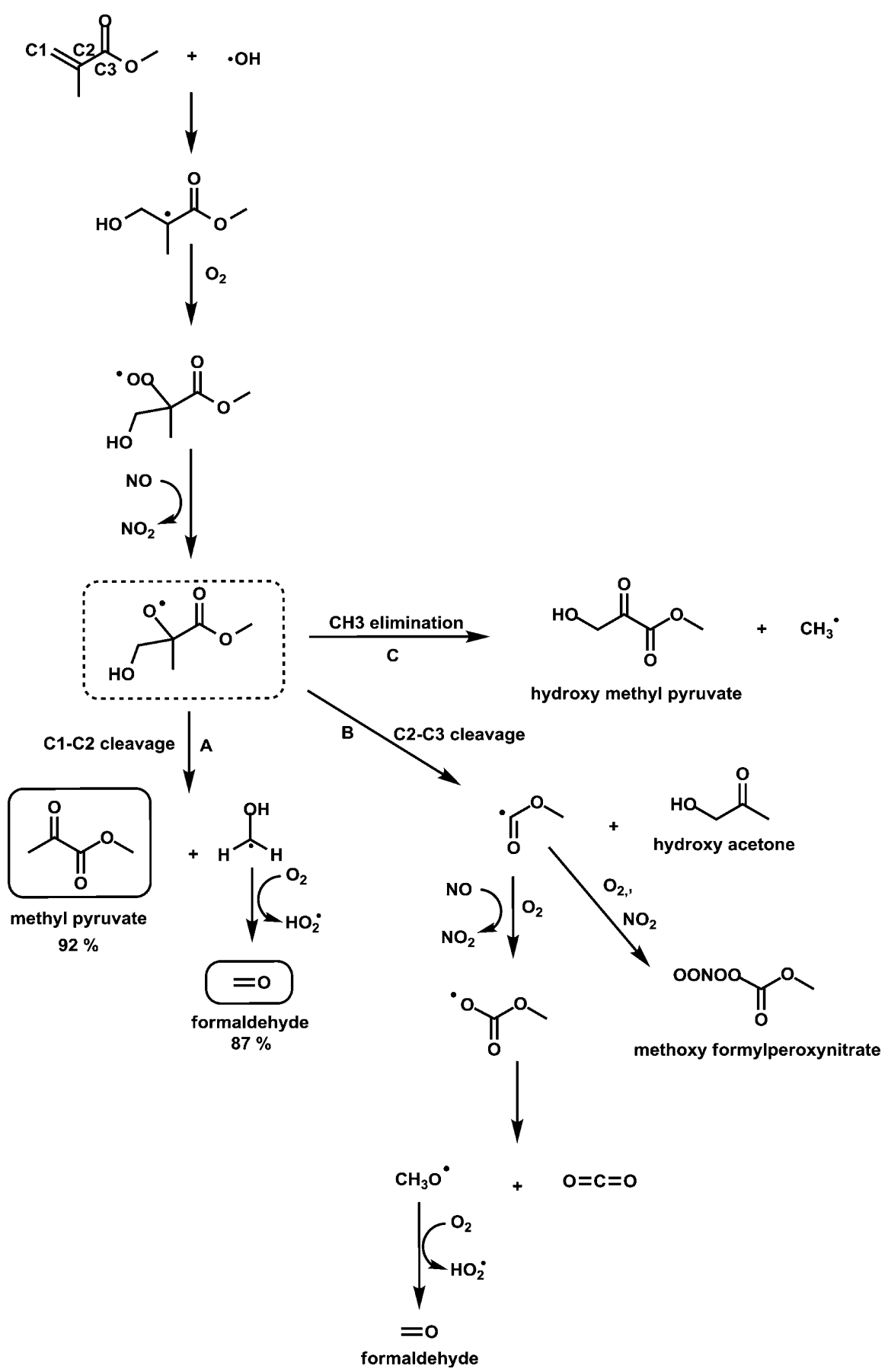

Figure 1. Simplified reaction mechanism for the addition channel in the OH-radical initiated oxidation of methyl methacrylate in the presence of NOx.

methacrylate in Figures 1 and 2, respectively. For the $\mathrm{OH}$ radical or $\mathrm{Cl}$ atom reactions, the major reaction pathway involves initial addition of the $\mathrm{OH}$ or $\mathrm{Cl}$ to the terminal carbon atom of the $\mathrm{C}=$ $\mathrm{C}$ bond, forming 1,2-hydroxyalkyl or 1,2-chloroalkyl radicals. ${ }^{31-33}$ In the case of $\mathrm{OH}$, the addition mechanism is expected to account for over $98 \%$ of the reaction. ${ }^{32,33}$ Similarly, the reaction of $\mathrm{Cl}$ atoms with methyl methacrylate is estimated to proceed by more than $98 \%$ via the addition of $\mathrm{Cl}$ to the double bond. ${ }^{34}$ Under the conditions of the present study, the hydroxyalkyl and 1,2-chloroalkyl radicals will react with $\mathrm{O}_{2}$ to form the corresponding 1,2-hydroxyalkyl or 1,2-chloroxyalkyl peroxy radicals. The peroxy radicals will then react further with NO to form nearly exclusively the 1,2-hydroxyalkoxy or 1,2- chloroalkoxy radicals, respectively. ${ }^{31-33}$ However, under $\mathrm{NO}_{x^{-}}$ free experimental conditions, peroxy self-reactions will occur. These will also result to a large extent in the formation of the alkoxy radicals; however, molecular channels are also possible which will result in the formation of multifunctional products. ${ }^{35}$

The 1,2-hydroxyalkoxy or 1,2-chloroalkoxy radicals can decompose by various channels (Figures 1 and 2) which include (i) decomposing to give methyl pyruvate and $\mathrm{CH}_{2} \mathrm{OH}$ or $\mathrm{CH}_{2} \mathrm{Cl}$ radicals, (ii) decomposing to give hydroxyacetone or chloroacetone and $\mathrm{CH}_{3} \mathrm{OC}(\mathrm{O})$ radicals, or (iii) ejecting a methyl group to form methyl-3-hydroxy-2-oxopropanoate or methyl-3chloro-2-oxopropanoate, i.e., $\mathrm{CH}_{2}(\mathrm{OH})-\mathrm{C}(\mathrm{O})-\mathrm{C}(\mathrm{O}) \mathrm{OCH}_{3}$ or $\mathrm{CH}_{2}(\mathrm{Cl})-\mathrm{C}(\mathrm{O})-\mathrm{C}(\mathrm{O}) \mathrm{OCH}_{3}$. 


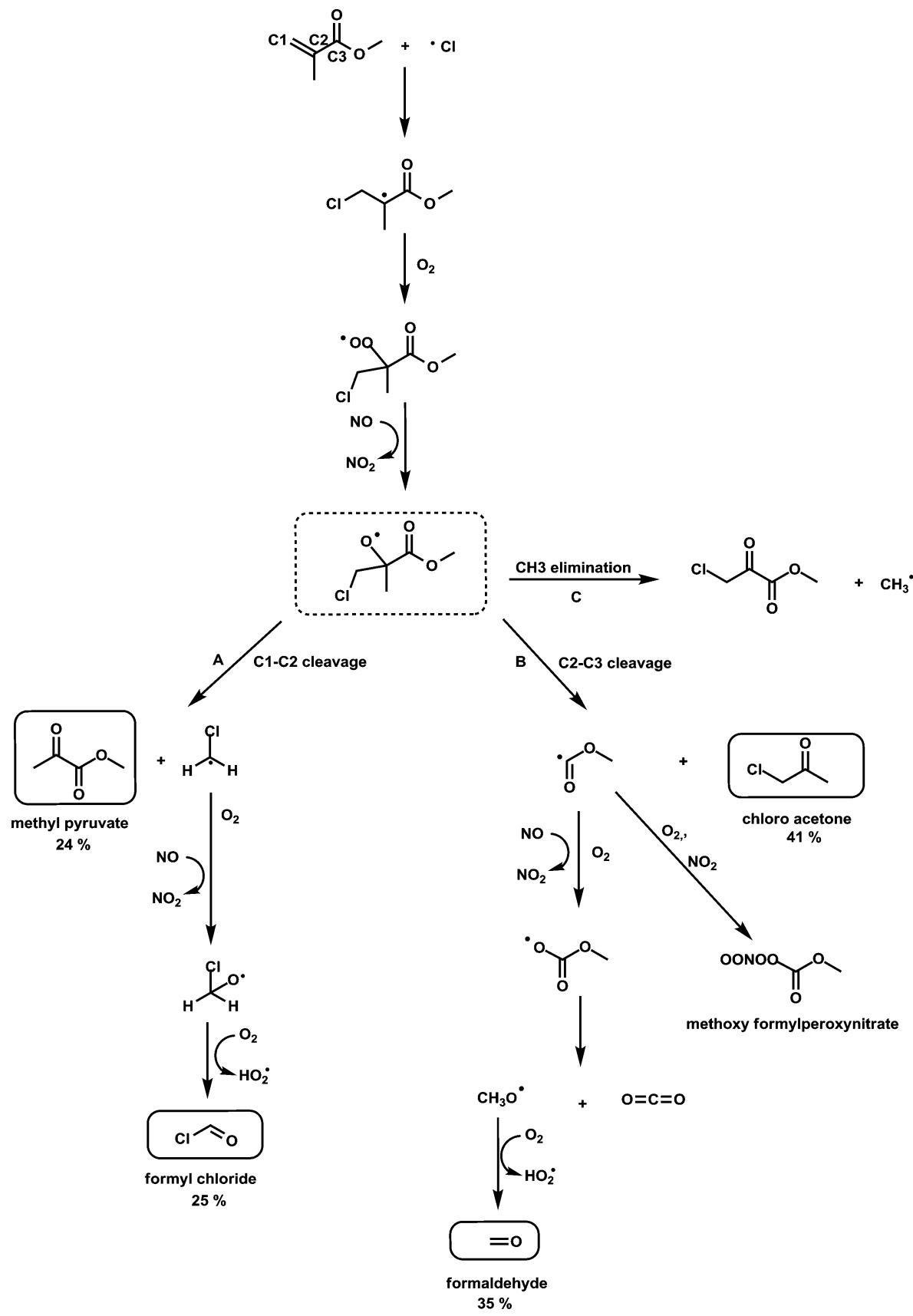

Figure 2. Simplified reaction mechanism for the addition channel in the Cl-atom-initiated oxidation of methyl methacrylate in the presence of NOx.

OH Reaction. Figure 3a shows IR spectra acquired before (panel A) and after (panel B) UV irradiation of a mixture of methyl methacrylate and $\mathrm{H}_{2} \mathrm{O}_{2}$ in air, in the presence of NOx. Panel $\mathrm{C}$ in Figure 3a, shows a reference spectrum of methyl pyruvate $\left(\mathrm{CH}_{3} \mathrm{C}(\mathrm{O}) \mathrm{C}(\mathrm{O}) \mathrm{OCH}_{3}\right)$ and panel $\mathrm{D}$, the residual product spectrum obtained after subtraction of reactants and identified products from the spectrum in panel B. Methyl pyruvate, $\mathrm{HCHO}$, and $\mathrm{CO}$ were readily identifiable as reaction products. In the residual product spectra, unidentified absorption bands were observed at 939, 1066, 1164, 1201, 1446, 1753, and $2970 \mathrm{~cm}^{-1}$. The concentration-time profiles of methyl pyruvate and $\mathrm{HCHO}$ (Figure $3 \mathrm{~b}$ ) show that they are both primary products, whereas the delayed formation in the profile of $\mathrm{CO}$ shows that formation is secondary in nature.

Least-squares analyses of plots of the concentrations of methyl pyruvate and $\mathrm{HCHO}$ as a function of the amount of reacted methyl methacrylate (Figure 3c) give molar yields of $92 \pm 16 \%$ and $83 \pm 12 \%$, respectively, for these compounds (see Table 1 ). Formaldehyde will be subject to secondary oxidation with $\mathrm{OH}$, whereas methyl pyruvate reacts only very slowly with $\mathrm{OH}$, and loss via secondary reaction with $\mathrm{OH}$ should be negligible. Correction of the $\mathrm{HCHO}$ yield for secondary reaction with $\mathrm{OH}$ using the method outlined in Tuazon et al. ${ }^{36}$ gives a final corrected yield of $87 \pm 12 \%$ for formaldehyde. The mechanism presented in Figure 1 (channel A) predicts equal yields of $\mathrm{HCHO}$ and methyl pyruvate, and within the experimental error limits, this is the case.

The absorption band observed at $1753 \mathrm{~cm}^{-1}$ in the residual product spectrum indicates the presence of other carbonylcontaining products; however, based on the measured yields of methyl pyruvate and $\mathrm{HCHO}$, the yields of these carbonyl products will be small. Other possible carbonyl-containing 


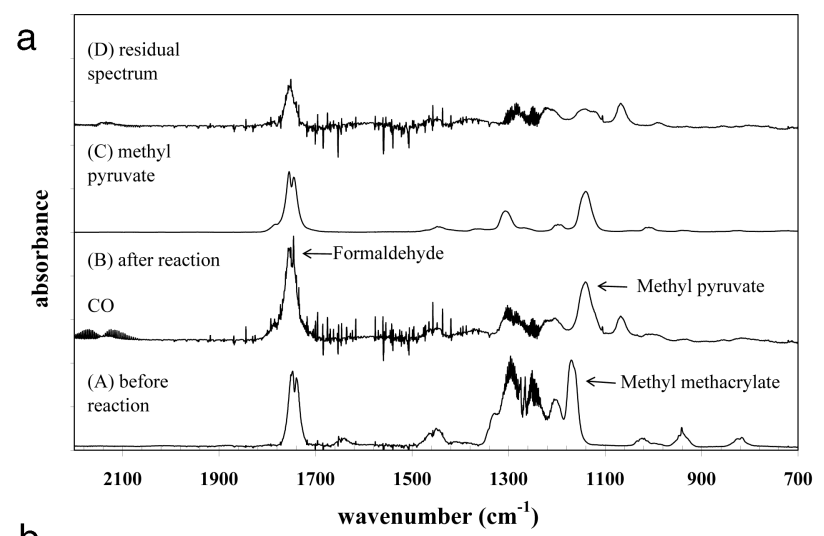

b
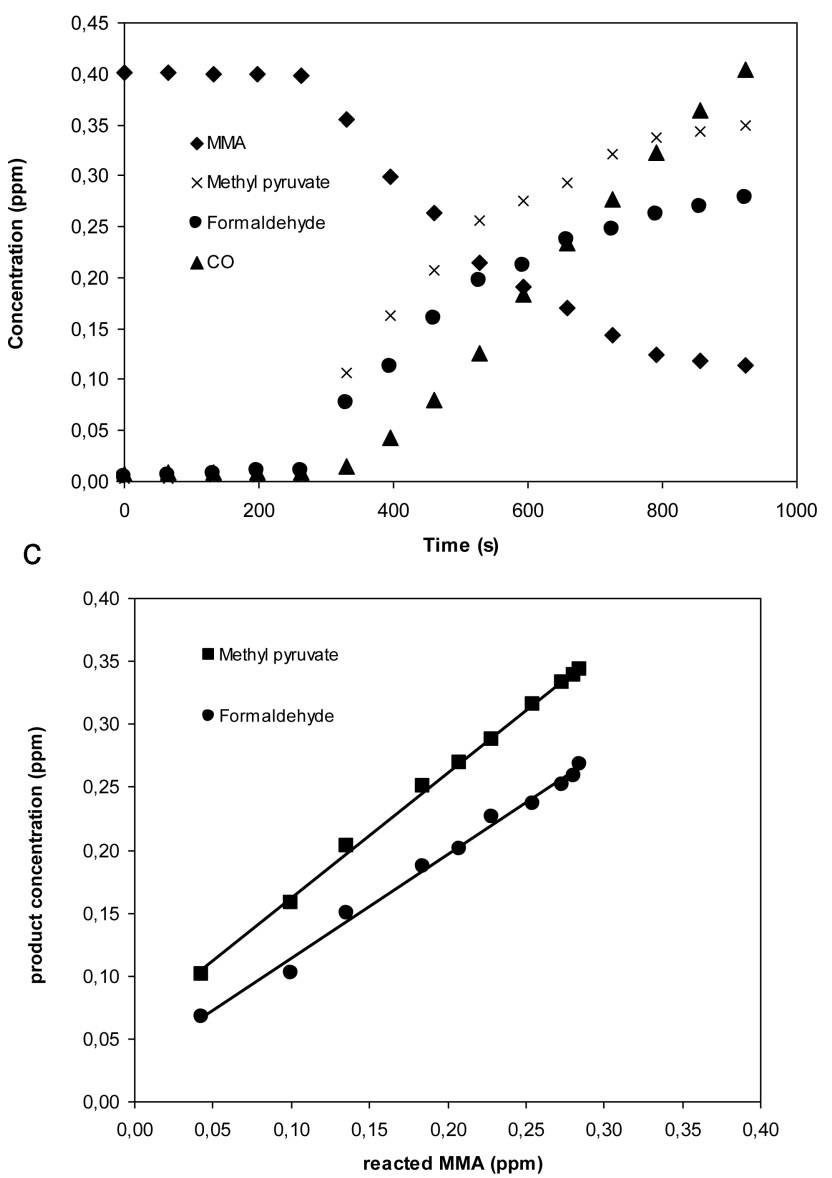

Figure 3. (a) Panel A: A spectrum of methyl methacrylate (MMA) in the spectral range $2200-700 \mathrm{~cm}^{-1}$ before irradiation in a $\mathrm{MMA} / \mathrm{H}_{2} \mathrm{O}_{2} /$ $\mathrm{NO} /$ air reaction mixture. Panel B: The product spectrum obtained after irradiation and subtraction of absorptions due to MMA. Absorptions due to the products $\mathrm{CO}$ and $\mathrm{HCHO}$ highlighted. Panel C: A reference spectrum of methyl pyruvate. Panel D: The residual spectrum obtained after subtraction of all identified products. (b) Concentration-time profiles of methyl methacrylate (MMA) and the reaction products methyl pyruvate, $\mathrm{HCHO}$, and $\mathrm{CO}$ obtained from the irradiation of a MMA/ $\mathrm{H}_{2} \mathrm{O}_{2} / \mathrm{NO} /$ air reaction mixture. (c) Plots of the concentrations of the reaction products methyl pyruvate and $\mathrm{HCHO}$ as a function of reacted methyl methacrylate (MMA) obtained from the irradiation of a $\mathrm{MMA} / \mathrm{H}_{2} \mathrm{O}_{2} / \mathrm{NO} /$ air reaction mixture.

products include (i) hydroxyl methyl pyruvate $\left(\mathrm{CH}_{3} \mathrm{OC}(\mathrm{O}) \mathrm{C}\right.$ (O) $\mathrm{CH}_{2}(\mathrm{OH})$ ) and hydroxy acetone $\left(\mathrm{CH}_{3} \mathrm{C}(\mathrm{O}) \mathrm{CH}_{2} \mathrm{OH}\right)$ produced by $\mathrm{CH}_{3}$ elimination from the 1,2-hydroxyalkoxy radical or a $\mathrm{C}_{2}-\mathrm{C}_{3}$ bond cleavage, channels $\mathrm{C}$ and $\mathrm{B}$, respectively
Table 1. Formation Yields of the Oxidation Products Identified from the $\mathrm{OH}$ Radical and $\mathrm{Cl}$ Atom Oxidation of Methyl Methacrylate in the Presence of NOx

\begin{tabular}{cll}
\multicolumn{1}{c}{ reaction } & \multicolumn{1}{c}{ product } & yield $(\%)^{a}$ \\
methyl methacrylate $+\mathrm{OH}$ & methyl pyruvate & $92 \pm 16$ \\
& formaldehyde & $87 \pm 12^{b}$ \\
methyl methacrylate $+\mathrm{Cl}$ & formylchloride & $25 \pm 4$ \\
& chloroacetone & $41 \pm 6$ \\
& methyl pyruvate & $24 \pm 4$ \\
& formaldehyde & $35 \pm 5^{c}$
\end{tabular}

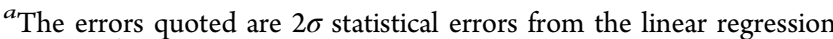
analysis. ${ }^{b}$ Yield corrected for secondary reaction with $\mathrm{OH}$ radicals. ${ }^{c}$ Yield corrected for secondary reaction with $\mathrm{Cl}$ atoms.

Figure 1, and (ii) $\mathrm{CH}_{3} \mathrm{OC}(\mathrm{O}) \mathrm{C}\left(\mathrm{CH}_{3}\right)(\mathrm{OH}) \mathrm{CHO}$ produced from reaction of $\mathrm{O}_{2}$ with the 2,1-hydroxyalkoxy radical formed from $\mathrm{OH}$ addition to the carbon of the double bond adjacent to the carbonyl entity of the ester group. No indication could be found in the product spectra for the formation of hydroxy acetone. The compound giving rise to the residual carbonyl absorption in the product spectrum is, therefore, most probably $\mathrm{CH}_{3} \mathrm{OC}(\mathrm{O}) \mathrm{C}\left(\mathrm{CH}_{3}\right)(\mathrm{OH}) \mathrm{CHO}$. On the basis of the yields of methyl pyruvate and $\mathrm{HCHO}$, the molar yield of $\mathrm{CH}_{3} \mathrm{OC}(\mathrm{O})$ $\mathrm{C}\left(\mathrm{CH}_{3}\right)(\mathrm{OH}) \mathrm{CHO}$ is estimated to be $<8 \%$.

$\mathrm{Cl}$ Reaction. Figure $4 \mathrm{a}$, panel A, shows a spectrum of a $\mathrm{MMA} / \mathrm{NO} / \mathrm{Cl}_{2} /$ air reaction mixture before irradiation, panel $\mathrm{B}$ the product spectra after $10 \mathrm{~min}$ irradiation and subtraction of spectral features due to MMA, and panel $\mathrm{C}$ the residual product spectrum after the subtraction of features attributable to the major identified MMA oxidation products from the spectrum in panel B. Chloroacetone $\left(\mathrm{CH}_{3} \mathrm{C}(\mathrm{O}) \mathrm{CH}_{2} \mathrm{Cl}\right)$, formaldehyde, methyl pyruvate, formyl chloride $(\mathrm{HC}(\mathrm{O}) \mathrm{Cl})$, and carbon monoxide were positively identified as reaction products. In the residual product spectra (Figure 4a, panel C), absorption bands can be seen in the regions $782-849 \mathrm{~cm}^{-1}, 1191-1308$ $\mathrm{cm}^{-1}$, and $1670-1840 \mathrm{~cm}^{-1}$.

Concentration-time profiles of $\mathrm{MMA}, \mathrm{CH}_{3} \mathrm{C}(\mathrm{O}) \mathrm{CH}_{2} \mathrm{Cl}$, $\mathrm{HC}(\mathrm{O}) \mathrm{Cl}, \mathrm{HCHO}, \mathrm{CH}_{3} \mathrm{C}(\mathrm{O}) \mathrm{C}(\mathrm{O}) \mathrm{OCH}_{3}$, and $\mathrm{CO}$ are shown in Figure $4 \mathrm{~b}$. The concentration-time profiles of $\mathrm{HCHO}$, $\mathrm{HC}(\mathrm{O}) \mathrm{Cl}$, and $\mathrm{CH}_{3} \mathrm{C}(\mathrm{O}) \mathrm{C}(\mathrm{O}) \mathrm{OCH}_{3}$ show that all are primary in origin, and the upward curve of the $\mathrm{CO}$ profile shows that its formation is secondary in nature. Secondary rapid reactions of $\mathrm{Cl}$ with $\mathrm{HCHO}$ will result in the formation of $\mathrm{CO}$. The amounts of $\mathrm{CH}_{3} \mathrm{C}(\mathrm{O}) \mathrm{CH}_{2} \mathrm{Cl}, \mathrm{HC}(\mathrm{O}) \mathrm{Cl}, \mathrm{HCHO}$, and $\mathrm{CH}_{3} \mathrm{C}(\mathrm{O}) \mathrm{C}(\mathrm{O})-$ $\mathrm{OCH}_{3}$ formed plotted as a function of the amount of reacted MMA are shown in Figure 4c. The plots are linear and give molar yields for formyl chloride, chloroacetone, methyl pyruvate, and formaldehyde of $25 \pm 4 \%, 41 \pm 6 \%, 24 \pm 4 \%$, and $23 \pm 3 \%$, respectively. The corrected yield of formaldehyde was $35 \pm 5 \%$.

The formation of chloroacetone shows that a major fate of the $\mathrm{CH}_{2}(\mathrm{Cl}) \mathrm{C}\left(\mathrm{CH}_{3}\right)\left(\mathrm{O}^{\bullet}\right) \mathrm{C}(\mathrm{O}) \mathrm{OCH}_{3}$ 1,2-chloroalkoxy radicals formed in the reaction of $\mathrm{Cl}$ with MMA in the presence of NOx is cleavage of the $\mathrm{C}_{2}-\mathrm{C}_{3}$ bond to form chloroacetone $\left(\mathrm{CH}_{3} \mathrm{C}(\mathrm{O}) \mathrm{CH}_{2} \mathrm{Cl}\right)$ and $\mathrm{CH}_{3} \mathrm{OC}(\mathrm{O})$ radicals with a yield of $\sim 41 \%$ (Figure 2, channel $\mathrm{B}$ ). The formation of $\mathrm{HC}(\mathrm{O}) \mathrm{Cl}$ and methyl pyruvate shows that cleavage of the $\mathrm{C}_{1}-\mathrm{C}_{2}$ bond to form these products (Figure 2, channel A) is also operative and accounts for around $25 \%$ of the reaction.

The identified products, however, account for only around $65 \%$ of the reacted MMA. Since all possible $\mathrm{C}-\mathrm{C}$ bond cleavage products have been detected and quantified, the missing product(s) must be in a form retaining all or most of the 


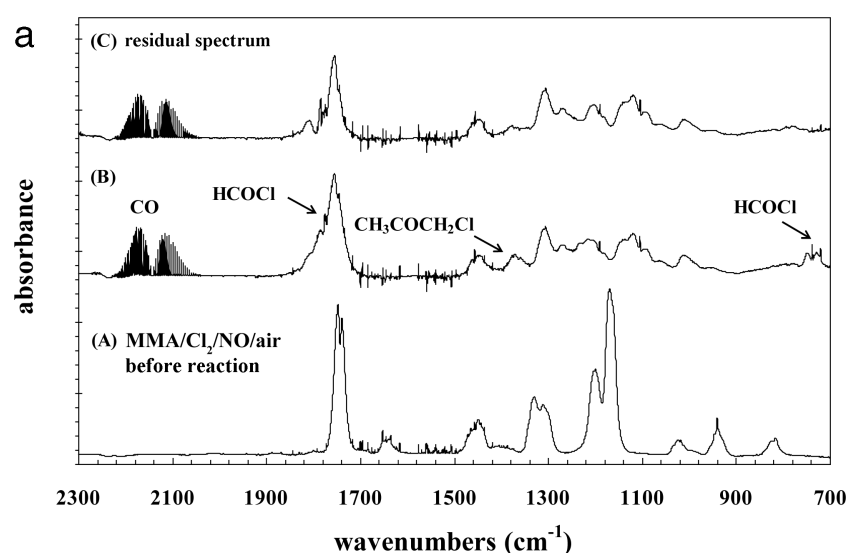

b

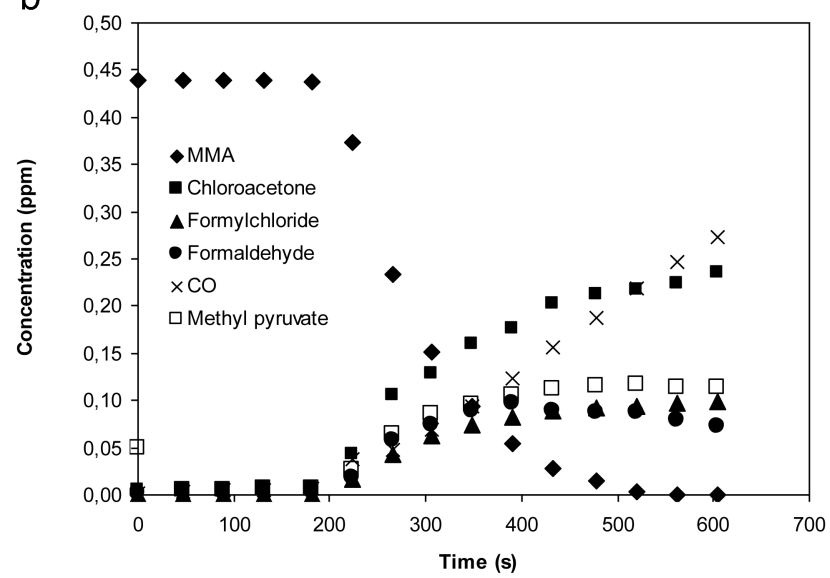

C

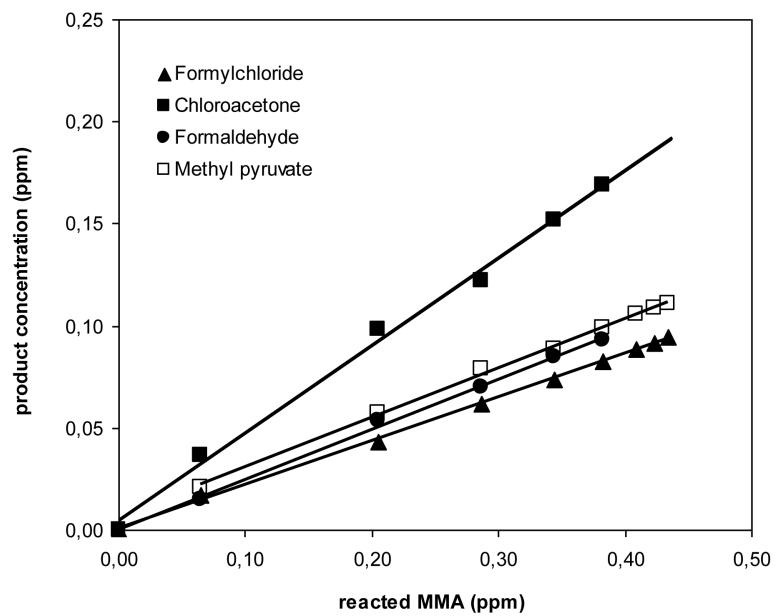

Figure 4. (a) Panel A: A spectrum of methyl methacrylate (MMA) in the spectral range $2300-700 \mathrm{~cm}^{-1}$ before irradiation in a $\mathrm{MMA} / \mathrm{Cl}_{2} /$ NO/air reaction mixture. Panel B: The product spectrum after irradiation and subtraction of features due to MMA. Absorptions due to the products $\mathrm{CO}, \mathrm{HC}(\mathrm{O}) \mathrm{Cl}$, and $\mathrm{CH}_{3} \mathrm{C}(\mathrm{O}) \mathrm{CH}_{2} \mathrm{Cl}$ are highlighted. Panel $\mathrm{C}$ shows the residual product spectrum after subtraction of $\mathrm{HC}(\mathrm{O}) \mathrm{Cl}, \mathrm{CH}_{3} \mathrm{C}(\mathrm{O}) \mathrm{CH}_{2} \mathrm{Cl}$ from the spectrum in panel B. (b) Concentration-time profiles of methyl methacrylate (MMA) and the reaction products $\mathrm{CH}_{3} \mathrm{C}(\mathrm{O}) \mathrm{CH}_{2} \mathrm{Cl}, \mathrm{HC}(\mathrm{O}) \mathrm{Cl}, \mathrm{CO}, \mathrm{HCHO}$, and methyl pyruvate obtained from the irradiation of a $\mathrm{MMA} / \mathrm{Cl}_{2} / \mathrm{NO} /$ air reaction mixture. $(\mathrm{C})$ : Plots of the concentrations of the reaction products $\mathrm{CH}_{3} \mathrm{C}(\mathrm{O}) \mathrm{CH}_{2} \mathrm{Cl}, \mathrm{HC}(\mathrm{O}) \mathrm{Cl}, \mathrm{CH}_{3} \mathrm{C}(\mathrm{O}) \mathrm{C}(\mathrm{O}) \mathrm{OCH}_{3}$ and $\mathrm{CH}_{2} \mathrm{O}$ as a function of reacted methyl methacrylate (MMA) obtained from the irradiation of a $\mathrm{MMA} / \mathrm{Cl}_{2} / \mathrm{NO} /$ air reaction mixture.

MMA carbon skeleton. Close inspection of the residual product spectrum (Figure 4a, panel C) shows that it contains absorptions from nitrosyl chloride (ClNO) and nitryl chloride $\left(\mathrm{ClNO}_{2}\right)$ formed from reactions of $\mathrm{Cl}$ with $\mathrm{NOx}$ in the system. Absorptions from nitric acid $\left(\mathrm{HNO}_{3}\right)$ are also visible. Although the residual product spectrum that is obtained after subtraction of these compounds is quite noisy, there is positive evidence for the presence of methoxy formylperoxynitrate $\left(\mathrm{CH}_{3} \mathrm{OC}(\mathrm{O})\right.$ $\mathrm{O}_{2} \mathrm{NO}_{2}$ ). This compound can be formed from consecutive reactions of the $\mathrm{CH}_{3} \mathrm{OC}(\mathrm{O})$ radical with $\mathrm{O}_{2}$ and $\mathrm{NO}_{2}$ and is reasonably thermally stable at room temperature. ${ }^{37-39}$ Other remaining absorptions strongly resemble those of the product observed in the reaction of $\mathrm{Cl}$ with methyl acrylate ${ }^{28}$ which was assigned to methyl-3-chloro-2-oxopropanoate $\left(\mathrm{CH}_{2}(\mathrm{Cl}) \mathrm{C}(\mathrm{O})\right.$ $\left.\mathrm{C}(\mathrm{O}) \mathrm{OCH}_{3}\right)$. The compound can be formed in the reaction of $\mathrm{Cl}$ with MMA via elimination of the $\mathrm{CH}_{3}$ group from the intermediate 1,2-chloroalkoxy radical, $\mathrm{CH}_{2}(\mathrm{Cl}) \mathrm{C}\left(\mathrm{CH}_{3}\right)\left(\mathrm{O}^{\bullet}\right) \mathrm{C}$ $(\mathrm{O}) \mathrm{OCH}_{3}$, i.e., pathway $\mathrm{C}$ in Figure 2, and could potentially account for $\leq 35 \%$ of the overall reaction. However, a contribution from the $\mathrm{C}$-skeleton retaining product methyl 2chloro-2-methyl-3-oxo-propanoate $\left(\mathrm{OCHC}(\mathrm{Cl})\left(\mathrm{CH}_{3}\right) \mathrm{C}(\mathrm{O})\right.$ $\left.\mathrm{OCH}_{3}\right)$, formed from reaction of 2,1-chloroalkoxy radicals, $\mathrm{OCH}_{2} \mathrm{CCl}\left(\mathrm{CH}_{3}\right) \mathrm{C}(\mathrm{O}) \mathrm{OCH}_{3}$, with $\mathrm{O}_{2}$ cannot be completely excluded.

The measured yield for $\mathrm{HCHO}$ is lower than that expected from the occurrence of pathway B in Figure 2; however, the observation of the formation of methoxy formylperoxynitrate supports that quite a substantial fraction of the $\mathrm{CH}_{3} \mathrm{OC}(\mathrm{O})$ radicals, formed in pathway $\mathrm{B}$, are retained in the form of this fairly stable peroxy nitrate. ${ }^{3-39}$

The finding that $\mathrm{OH}$ addition to the double bond in MMA results in close to unity cleavage of the $\mathrm{C}_{1}-\mathrm{C}_{2}$ bond to form methyl pyruvate and $\mathrm{CH}_{2} \mathrm{OH}$ radicals, which react further to form $\mathrm{HCHO}$, is in agreement with the findings of a previous GCMS product determination study on the reactions of $\mathrm{OH}$ with methyl methacrylate, ethyl methacrylate, and $n$-butyl methacrylate. $^{12}$

The results contrast sharply with those obtained for the reaction of $\mathrm{Cl}$ with MMA, where although cleavage of the $\mathrm{C}_{1}-\mathrm{C}_{2}$ bond to form methyl pyruvate and formyl chloride was observed, it only accounted for around $25 \%$ of the degradation mechanism. Cleavage of the $\mathrm{C}_{2}-\mathrm{C}_{3}$ bond to form chloroacetone and $\mathrm{CH}_{3} \mathrm{OC}(\mathrm{O})$ radicals was found to be a more important channel with a yield of around $41 \%$. Further, the gap in the carbon balance and the lack of other $\mathrm{C}-\mathrm{C}$ bond cleavage products in the residual product spectrum supports that a $\mathrm{C}$-chain retaining channel is also operative, leading most probably to the formation of $\mathrm{CH}_{2} \mathrm{ClC}(\mathrm{O}) \mathrm{C}(\mathrm{O}) \mathrm{OCH}_{3}$.

This product channel branching behavior observed for the reaction of $\mathrm{Cl}$ with MMA not only contrasts sharply with that of the analogous $\mathrm{OH}$ reaction as stated above but also with that observed for the reaction of $\mathrm{Cl}$ with methyl acrylate (MA) where no $\mathrm{C}-\mathrm{C}$ bond cleavage was observed, ${ }^{28}$ and the only product channel was assumed to be a C-chain retaining product, i.e., $\mathrm{CH}_{2} \mathrm{ClC}(\mathrm{O}) \mathrm{C}(\mathrm{O}) \mathrm{OCH}_{3}$, the same product that is thought to be formed in the $\mathrm{Cl} / \mathrm{MMA} / \mathrm{NO}$ reaction through elimination of a $\mathrm{CH}_{3}$ group from the MMA C-skeleton. This dramatic difference in the contributions of the various reaction channels to the fate of the 1,2-hydroxyalkoxy and 1,2-chloroalkoxy formed in the reactions of $\mathrm{OH}$ and $\mathrm{Cl}$ with MA and MMA can probably be attributed to the differences in the distribution of the excess energy in the hydroalkoxy and chloroalkoxy radicals arising from the exothermic reactions of the corresponding peroxy radicals with NO. It would be interesting to study any changes in the product distributions when the 1,2-hydroxyalkoxy and 1,2- 
chloroalkoxy are formed via nearly thermo-neutral peroxyperoxy reactions. Such information is necessary for modeling the oxidation of the VOCs in low NOx regimes.

Reactions of $\mathrm{Cl}$ atoms with VOCs are often used as a surrogate for the corresponding $\mathrm{OH}$ reactions since the $\mathrm{Cl}$ reactions are approximately 1 order of magnitude faster, are generally easier to study, and are assumed to proceed by similar reaction mechanisms. These studies show that, although these assumptions are probably true for mechanisms involving only $\mathrm{H}$-atom abstraction, care should be taken into account when addition to alkene entities is involved in the mechanism since branching ratios for the possible product channels can be completely different and would lead to completely wrong reaction schemes and prediction of environmental impacts if transferred to the $\mathrm{OH}$ radical.

The persistence of methacrylates in the atmosphere is short, on the order of a few hours (dominated by $\mathrm{OH}$ radical chemistry). ${ }^{14,22}$ These short lifetimes indicate that the methacrylates will be degraded close to their emission sources. Since the degradation products can contribute to ozone and photooxidants formation in the troposphere to different degrees, it is important to know the product branching for different atmospheric conditions. This study and ongoing work in our laboratories supports that the product branching ratios for the reactions of $\mathrm{OH}$ radicals and $\mathrm{Cl}$ atoms with acrylate esters are particularly NOx sensitive and need further investigation to correctly represent the oxidation mechanisms of this class of compounds in atmosphere CT models.

\section{AUTHOR INFORMATION}

\section{Corresponding Author}

*E-mail: mteruel@fcq.unc.edu.ar.

\section{Notes}

The authors declare no competing financial interest.

\section{ACKNOWLEDGMENTS}

Maria B. Blanco wishes to acknowledge the Alexander von Humboldt Foundation (AvH), and the authors wish to acknowledge Deutsche Forschungsgemeinschaft (DFG), DAAD-PROALAR (Germany), the EU project EUROCHAMP2, SECYT (Argentina), and CONICET (Argentina) for financial support of this research.

\section{REFERENCES}

(1) BASF Golobal - BASF - The Chemical Company - Corporate Website. http://www.basf.com.

(2) Graedel, T. E. Chemical Compounds in the Atmosphere; Academic Press: New York, 1978.

(3) Organization for Economic Co-operation and Development. http://cs3-hq.oecd.org/scripts/hpv/index.asp.

(4) Pankow, J. F.; Luo, W.; Bender, D. A.; Isabelle, L. M.; Hollingsworth, J. S.; Chen, C.; Asher, W. E.; Zogorski, J. S. Concentrations and co-occurrence correlations of 88 volatile organic compound (VOCs) in the ambient air of 13 semi-rural to urban locations in the United Sates. Atmos. Environ. 2003, 37, 5023-5046.

(5) Finlayson-Pitts, B. J.; Pitts, J. N., Jr. Chemistry of the Upper and Lower Atmosphere; Academic Press, New York, 2000.

(6) Wingenter, O. W.; Kubo, M. K.; Blake, N. J.; Smith, T. W.; Blake, D. R.; Rowland, F. S. Hydrocarbon and halocarbon measurements as photochemical and dynamical indicators of atmospheric hydroxyl, atomic chlorine and vertical mixing obtained during Langrangian flights. J. Geophys. Res. 1996, 101, 4331-4340.
(7) Spicer, C. W.; Chapman, E. G.; Finlayson-Pitts, B. J.; Plastidge, R. A.; Hubbe, J. M.; Fast, J. D.; Berkowitz, C. M. Observations of molecular chlorine in coastal air. Nature 1998, 394, 353-356.

(8) Ezell, M. J.; Wang, W.; Ezell, A. A.; Soskin, G.; Finlayson-Pitts, B. J. Kinetics of reactions of chlorine atoms with a series of alkenes at $1 \mathrm{~atm}$ and 298 K: structure and reactivity. Phys. Chem. Chem. Phys. 2002, 4, 5813-5820.

(9) Thornton, J. A.; Kercher, J. P.; Riedel, T. P.; Wagner, N. L.; Cozic, J.; Holloway, J. S.; Dubé, W. P.; Wolfe, G. M.; Quinn, P. K.; Middlebrook, A. M.; Alexander, B.; Brown, S. S. A large atomic chlorine source inferred from mid-continental reactive nitrogen chemistry. Nature 2010, 464, 271-274.

(10) Saunders, S. M.; Baulch, D. L.; Cooke, K. M.; Pilling, M. J.; Smurthwaite, P. I. Kinetics and mechanisms of the reactions of $\mathrm{OH}$ with some oxygenated compounds of importance in tropospheric chemistry. Int. J. Chem. Kinet. 1994, 26, 113-130.

(11) Teruel, M. A.; Lane, S. I.; Mellouki, A.; Solignac, G.; Le Bras, G. $\mathrm{OH}$ reaction rate constants and $\mathrm{UV}$ absorption cross-sections of unsaturated esters. Atmos. Environ. 2006, 40, 3764-3772.

(12) Blanco, M. B.; Taccone, R. A.; Lane, S. I.; Teruel, M. A. On the $\mathrm{OH}$-initiated degradation of methacrylates in the troposphere: gasphase kinetics and formation of pyruvates. Chem. Phys. Lett. 2006, 429, 389-394.

(13) Blanco, M. B.; Teruel, M. A. Photodegradation of butyl acrylate in the troposphere by $\mathrm{OH}$ radicals: kinetics and fate of 1,2-hydroxyalcoxy radicals. J. Org. Chem. 2008, 21, 397-401.

(14) Blanco, M. B.; Bejan, I.; Barnes, I.; Wiesen, P.; Teruel, M. A. OHInitiated Degradation of Unsaturated Esters in the Atmosphere: Kinetics in the Temperature Range of 287-313 K. J. Phys. Chem. A. 2009, 113, $5958-5965$

(15) Munshi, H. B.; Rao, K. V. S. R.; Iyer, R. M. Rate constants of the reactions of ozone with nitriles, acrylates and terpenes in gas phase. Atmos. Environ. 1989, 23, 1971-1976.

(16) Grosjean, D.; Grosjean, E.; Williams, E. L., II. Rate constants for the gas-phase reactions of ozone with unsaturated alcohols, esters, and carbonyls. Int. J. Chem. Kinet. 1993, 25, 783-794.

(17) Grosjean, E.; Grosjean, D. Rate constants for the gas-phase reaction of ozone with unsaturated oxygenates. Int. J. Chem. Kinet. 1998, 30, 21-29.

(18) Gai, Y. B.; Ge, M. F.; Wang, W. G. Rate constants for the gas phase reaction of ozone with n-butyl acrylate and ethyl methacrylate. Chem. Phys. Lett. 2009, 473, 57-60.

(19) Al Mulla, I.; Viera, L.; Morris, R.; Sidebottom, H.; Treacy, J.; Mellouki, A. Kinetics and Mechanisms for the reactions of ozone with unsaturated oxygenated compounds. Chem. Phys. Chem. 2010, 11, 4069-4078.

(20) Bernard, F.; Eyglunent, G.; Daele, V.; Mellouki, A. Kinetics and Products of Gas-Phase Reactions of Ozone with Methyl Methacrylate, Methyl Acrylate, and Ethyl Acrylate. J. Phys. Chem. A 2010, 114, 83768383.

(21) Blanco, M. B.; Bejan, I.; Barnes, I.; Wiesen, P.; Teruel, M. A. The Cl-initiated oxidation of $\mathrm{CH}_{3} \mathrm{C}(\mathrm{O}) \mathrm{OCH}=\mathrm{CH}_{2}, \mathrm{CH}_{3} \mathrm{C}(\mathrm{O})$ $\mathrm{OCH}_{2} \mathrm{CH}=\mathrm{CH}_{2}$, and $\mathrm{CH}_{2}=\mathrm{CHC}(\mathrm{O}) \mathrm{O}\left(\mathrm{CH}_{2}\right)_{3} \mathrm{CH}_{3}$ in the troposphere. Env. Sci. Pollut. Res. 2009, 16, 641-648.

(22) Blanco, M. B.; Bejan, I.; Barnes, I.; Wiesen, P.; Teruel, M. A. Temperature-dependent rate coefficients for the reactions of $\mathrm{Cl}$ atoms with methyl methacrylate, methyl acrylate and butyl methacrylate at atmospheric pressure. Atmos. Environ. 2009, 43, 5996-6002.

(23) Martín, M. P.; Gallego-Iniesta, M. P.; Espinosa, J. L.; Tapia, A.; Cabaňas, B.; Salgado, M. S. Gas phase reactions of unsaturated esters with $\mathrm{Cl}$ atoms. Env. Sci. Pollut. Res. 2010, 17, 539-546.

(24) Canosa-Mas, C. E.; Carr, S.; King, M. D.; Shallcross, D. E.; Thompson, K. C.; Wayne, R. P. A kinetic study of the reaction of $\mathrm{NO}_{3}$ with methyl vinyl ketone, methacrolein, acrolein, methyl acrylate and methyl methacrylate. Phys. Chem. Chem. Phys. 1999, 1, 4195-4202.

(25) Wang, K.; Ge, M.; Wang, W. Kinetics of the gas-phase reactions of $\mathrm{NO}_{3}$ radicals with ethyl acrylate, $n$-butyl acrylate, methyl methacrylate and ethyl acrylate. Atmos. Environ. 2010, 44, 1847-1850. 
(26) Salgado, M. S.; Gallego-Iniesta, M. P.; Martín, M. P.; Tapia, A.; Cabañas, B. Night-time atmospheric chemistry of methacrylates. Env. Sci. Pollut. Res. 2011, 18, 940-948.

(27) Canosa-Mas, C. E.; Flugge, M. L.; King, M. D.; Wayne, R. P. An experimental study of the gas-phase reaction of the $\mathrm{NO}_{3}$ radical with $\alpha, \beta$ unsaturated carbonyl compounds. Phys. Chem. Chem. Phys. 2005, 7, 643-650.

(28) Blanco, M. B.; Bejan, I.; Barnes, I.; Wiesen, P.; Teruel, M. A. FTIR Product Distribution Study of the $\mathrm{Cl}$ and $\mathrm{OH}$ Initiated Degradation of Methyl Acrylate at Atmospheric Pressure. Environ. Sci. Technol. 2010, 44, 7031-7036.

(29) Butt, C. M.; Young, C. J.; Mabury, S. A.; Hurley, M. D.; Wallington, T. J. Atmospheric Chemistry of 4:2 Fluorotelomer acrylate $\left[\mathrm{C}_{4} \mathrm{~F}_{9} \mathrm{CH}_{2} \mathrm{CH}_{2} \mathrm{OC}(\mathrm{O}) \mathrm{CH}=\mathrm{CH}_{2}\right]$ : kinetics, mechanisms, an products of chlorine-atom-and OH-radical-initiated oxidation. J. Phys. Chem. A 2009, 113, 3155-3161.

(30) Barnes, I.; Becker, K. H. An FTIR Product Study of the Photooxidation of Dimethyl Disulfide. J. Atmos. Chem. 1994, 18, 267289.

(31) Calvert, J. G.; Atkinson, R.; Kerr, J. A.; Madronich, S.; Moortgat, G. K.; Wallington, T. J.; Yarwood, G. The Mechanisms of Atmospheric Oxidation of Alkenes; Oxford University Press: New York; ISBN: 0195131770, 2000.

(32) Atkinson, R.; Arey, J. Atmospheric degradation of volatile organic compounds. Chem. Rev. 2003, 103, 4605-4638.

(33) Atkinson, R. Gas Phase Tropospheric Chemistry of Volatile Organic Compounds: 1. Alkanes and Alkenes. J. Phys. Chem. Ref. Data 1997, 26, 215-290.

(34) Aschmann, S. M.; Atkinson, R. Rate constants for the gas-phase reactions of alkanes with $\mathrm{Cl}$ atoms at $296 \pm 2 \mathrm{~K}$. Int. J. Chem. Kinet. 1995, 27, 613-622.

(35) Lightfoot, P. D.; Cox, R. A.; Crowley, J. N.; Destriau, M.; Hayman, G. D.; Jenkin, M. E.; Moortgat, G. K.; Zabel, F. Organic peroxy radicals: kinetics, spectroscopy and tropospheric chemistry. Atmos. Environ. 1992, 26A, 1805-1964.

(36) Tuazón, E. C.; MacLeod, H.; Atkinson, R.; Carter, W. P. L. $\alpha$ Dicarbonyl yields from $\mathrm{NO}_{x}$-air photooxidations of a series of aromatic hydrocarbons in air. Environ. Sci. Technol. 1986, 20, 383-387.

(37) Cavalli, F.; Barnes, I.; Becker, K. H.; Wallington, T. J. Atmospheric oxidation mechanism of methyl propionate. J. Phys. Chem. A 2000, 104, $11310-11317$

(38) Orlando, J. J.; Tyndall, G. S. The atmospheric oxidation of ethyl formate and ethyl acetate over a range of temperatures and oxygen partial pressures. Int. J. Chem. Kinet. 2010, 42, 397-413.

(39) Pimentel, A. S.; Tyndall, G. S.; Orlando, J. J.; Hurley, M. D.; Wallington, T. J.; Sulbaek Andersen, M. P.; Marshall, P.; Dibble, T. S. Atmospheric chemistry of isopropyl formate and tert-butyl formate. Int. J. Chem. Kinet. 2010, 42, 479-498. 